\title{
Partner notification for sexually transmitted infections and perception of notified partners
}

\author{
Notificação de parceiros sexuais com infecção sexualmente \\ transmissível e percepções dos notificados \\ Notificación de parejas sexuales con infección transmitida \\ sexualmente y percepciones de los notificados
}

Elani Graça Ferreira Cavalcante ${ }^{1}$, Mahara Coelho Crisostomo Miranda ${ }^{2}$, Ana Zaiz Flores Hormain Teixeira de Carvalho' Ivana Cristina Vieira de Lima ${ }^{1}$, Marli Teresinha Gimeniz Galvão ${ }^{3}$

How to cite this article:

Cavalcante EGF, Miranda MCC, Carvalho AZFHT, Lima ICV, Galvão MTG. Partner notification for sexually transmitted infections and perception of notified partners. Rev Esc Enferm USP. 2016;50(3):448-455. DOI: http://dx.doi.org/10.1590/S0080-623420160000400011

\author{
${ }^{1}$ Universidade Federal do Ceará, \\ Programa de Pós-Graduação em \\ Enfermagem, Fortaleza, CE, Brazil. \\ ${ }^{2}$ Universidade Federal do Ceará, \\ Faculdade de Farmácia, Odontologia e \\ Enfermagem, Fortaleza, CE, Brazil. \\ ${ }^{3}$ Universidade Federal do Ceará, Departamento \\ de Enfermagem, Fortaleza, CE, Brazil.
}

\begin{abstract}
Objective: Learn the perceptions of patients with sexually transmitted infections and sexual partners who are notified of the infection. Method: A descriptive and qualitative study, based on the collective subject discourse technique, was conducted in four healthcare centers of reference in Fortaleza, Ceará, from March to July 2014. The sample comprised 21 subjects (11 index patients and 10 notified partners). Results: The index patients reported complicity, concern about the partner's health and revelation of diagnosis aiming to preserve the relationship. The partners showed antagonistic perceptions: tranquilitybetrayal, fear of death, of incurability and the diagnosis, especially of HIV. The reasons for coming to a healthcare center were: fear of being sick, attenuation of guilt of infection transmission, need for diagnosis, early start of treatment. Conclusion: Fear of losing trust, insecurities when dealing with a sexual infection and being responsible or coresponsible for the transmission were the predominant feelings. Various types of partner notification were reported (verbal, telephone, notification card), according to individual convenience. This study suggests the use of alternative methods of notification and an integrated system of notification.
\end{abstract}

\section{DESCRIPTORS}

Sexually Transmitted Diseases; HIV Infections; Sexual Partners; Contact Tracing; Public Health Nursing. 


\section{INTRODUCTION}

To interrupt the transmission cycle of sexually transmitted infections (STIs), the treatment of people involved in sexual relationships is essential. For this reason, sexual partners should be notified, a process through which the sexual contacts of an index patient (patient who has been diagnosed with an STI) are identified and informed of their exposure and invited to get tested, receiving counseling and treatment, as needed ${ }^{(1)}$.This action is recommended to be voluntary, conducted in proper, social and legal environments ${ }^{(2-3)}$.

Properly conducted notification reduces persistent infection of index patients, identifies asymptomatic sexual infections, helps reduce infection transmission, prevents sequelae and offers an opportunity for discussion about safe $\operatorname{sex}^{(1,2)}$.

Partner notification in Brazil may be conducted by the person diagnosed with an STI (index patient), or by a health professional. Notification by an index patient is when this patient, encouraged by a health professional, is in charge of informing his/her diagnosis to his/her partners for testing and health counseling services. This notification may be verbal or through a sexual partner card provided by a healthcare center. The notification via health professional may take place through correspondence, telephone or electronic contact, or active search, provided the principles of confidentiality and secrecy are observed ${ }^{(3)}$.

However, despite the national recommendation methods, there is no study in the country showing how partners are notified and what strategies are currently used in health services. Improper notification is one of the main factors associated with the challenge of STI control ${ }^{(4-5)}$, especially syphilis, whose non-treatment of partners of infected pregnant women is frequently mentioned as one of the causes of congenital syphilis in the country ${ }^{(6)}$.

In the United States and in Europe, partner notification has become a strategy of HIV prevention, and it is related to the increased search for counseling and testing among sexual partners notified by index patients diagnosed with the virus $^{(1-2,4)}$. Partner notification actions in case of index patients with syphilis, gonorrhea, chlamydia and HIV in most European countries are priorities and the main responsibility of specialty health providers from reference clinics $^{(2)}$.

Regardless of the partner notification method, during the service to a person diagnosed with an STI, the health professional has to discuss about the importance of partner notification, explaining the information confidentiality process, the possibility of partners being infected and asymptomatic, the risks of reinfection and consequences of non-treatment ${ }^{(5)}$.

Studies indicate the need to review how partners are approached at the primary healthcare level, aiming to implement strategies to encourage contact from sexual partners with STI, in compliance with health service organization logic and the perspective of people involved in this action ${ }^{(6-7)}$.

Health services, at national level, are not prepared to notify partners in a proper manner, particularly in STI healthcare centers, which offer diagnosis, treatment and follow-up services to index patients, and where the inclusion of sexual partners is essential for the interruption of infection transmission ${ }^{(8)}$.

The findings of this study can help understand the aspects related to the subjectivity of everyone involved in partner notification for better handling of STI cases, especially considering the limitations and obstacles found by professionals, particularly primary healthcare nurses ${ }^{(9)}$. Efforts in this sense can help understand how sexual partners are incorporated into healthcare services and aid the development of strategies that increase access of sexual partners.

Thus, to increase the knowledge related to partner notification, particularly in the perspective of index patients and their sexual partners, the objective of this study was to learn the perceptions of patients with sexually transmitted infections and sexual partners regarding the notification of STIs.

\section{METHOD}

This is a descriptive and qualitative study, conducted in all four healthcare centers providing services to STI patients in Fortaleza, Ceará. Each center has a multidisciplinary team for cases of spontaneous demand and/or referred by the primary healthcare system, offering counseling, rapid testing and laboratory services and ensuring diagnostic tests and follow-up. Three healthcare centers are references for HIV patients and one for STI patients.

Data were collected from March to July 2014. A purposive sampling approach was adopted, in which subjects were identified using information provided by health professionals who delivered care in the centers in the study period. As STI cases were identified as fulfilling the study objectives and criteria, the person (sexual partner or index patient) was invited to participate in the study.

The inclusion criteria were: 1 . People with serological diagnosis of sexually transmitted infections and/or syndrome associated with sexually transmitted infections ${ }^{(3)}$, or index patients, who have sexual partners to be notified, regardless of any affectional-sexual bond, and that were willing to notify their partners; 2 . Sexual partners notified by index patients or health professionals and who had gone to healthcare centers for testing/counseling.

This study had, in total, 21 participants: 11 index patients and 10 notified partners. It used data saturation and repetition of testimonial information, and had no intention to study pairs (index patients and notified partners) from the same case, but broadly investigate people with STIs and sexual partners.

A semi-structured interview was used to collect data about gender, age, schooling, occupation and diagnosis of index patient who generated the notification. Two guiding questions were made to index patients: What made you invite your sexual partner to go to a healthcare center? How did you notify your partner of the need to go to a healthcare center? And the following guiding questions were made to sexual partners: How did you feel when you were notified/ invited to go to a healthcare center? What made you accept this invitation?

Full testimonials of all interviewees were recorded using a digital recorder to ensure high-quality data reproduction. 
The interviews were conducted by a trained investigator in a separate environment to ensure privacy. Each interview lasted on average 20 minutes and was fully transcribed and analyzed using the collective subject discourse (CSD) technique.

This technique proposes the organization and tabulation of qualitative data obtained verbally using the most representative excerpts of the speech, that is, the key expressions showing the essence of the testimonial content. The CSD method is made up of four operators: key expression, central ideas, anchors and collective subject discourse. Key expressions are excerpts of the speech highlighted by the investigator that represent the essence of the testimonial content. Central ideas are words or expressions that show, in a clear and objective manner, the sense of testimonials. An anchor is a general statement used to "frame" particular situations. And lastly, the CSD is a summarized speech written in the first person singular that combines key expressions with equivalent central ideas or anchors ${ }^{(10,11)}$.

The analysis of testimonials using the CSD technique involved six phases ${ }^{(10,11)}$ : I. Full transcription of answers from each subject; II. Identification of key expressions, central ideas and anchors in each answer; III. Descriptions of the central idea and anchors extracted from the key expressions, placing them in the corresponding column; IV. Grouping of central ideas with common meanings, assigning a letter to each group; V. Creation of a summarized central ideal for each group; VI. CSD construction based on the summarized central idea.

The results of this study were presented in tables, one showing the perception of index patients and one showing the perception of sexual partners, containing the guiding questions, central ideas and collective subject discourses.

The research proposal was approved by the Research Ethics Committee of the Universidade Federal do Ceará, under protocol number 550.145. The objectives of this study were explained to all participants, who signed an informed consent form.

\section{RESULTS}

Of all 11 index patients with STI, five were men and six were women, between 20 and 29 years of age, most were single and heterosexual, with complete or incomplete high school, employed, and had a family income between one and three minimum wages (one minimum wage in the study period was BRL 544). Most index patients had a stable partner (with an affectional bond regardless of a marital relationship) for less than 12 months. Regarding the diagnoses of index patients, four had HIV, four had syphilis, one had syphilis/ HIV coinfection, one had the male urethritis associated with gonorrhea/chlamydia infection, and one had genital wart associated with human papillomavirus (HPV) infection. Therefore, diagnoses of HIV and syphilis infection were predominant among the reasons of partner notification.

Among all 10 sexual partners (five men and five women) investigated, age varied from 20 to 48 years and the predominant school level was complete high school and higher education; six of them were single and four were married; seven were heterosexual and three were homosexual. Most of them reported a family income between one and five minimum wages. Among the reasons mentioned by the partners for going to a healthcare center, six resulted from HIV infection notified by index patients. In addition, syphilis and the syndromes associated with sexually transmitted infections (genital warts and male urethritis) were predominant. Partner notification allowed to identify two cases of asymptomatic STI (one HIV infection and one due to syphilis) among the 10 interviewees.

Chart 1 shows index patients' perceptions of infection notification.

Chart 1 - Index patients' perceptions of infection notification - Fortaleza, Ceará, Brazil, March - July 2014.

\begin{tabular}{|c|c|c|}
\hline \multicolumn{3}{|r|}{ Index patients } \\
\hline Guiding question & Central idea & Collective Subject Discourse \\
\hline \multirow{4}{*}{$\begin{array}{l}\text { What made you invite your } \\
\text { sexual partner to go to a } \\
\text { healthcare center? }\end{array}$} & Mutual support & $\begin{array}{l}\text { At first, I thought I wouldn't say anything about it, I got desperate and } \\
\text { afraid of his/her reaction. But then I decided to tell him/her the truth, as } \\
\text { it would be wrong if only I were treated and it would be in vain. Besides, } \\
\text { I don't have secrets with him/her, then I thought I'd better tell. It's up to } \\
\text { him/her to keep this relationship with me. }\end{array}$ \\
\hline & $\begin{array}{l}\text { Concern about the } \\
\text { partner }\end{array}$ & $\begin{array}{l}\text { I worry and care about my partner and for this reason I want him/her to } \\
\text { get tested. If the result is positive, he/she can start the treatment as soon } \\
\text { as possible and be healthy. }\end{array}$ \\
\hline & $\begin{array}{l}\text { Relationship } \\
\text { preservation }\end{array}$ & $\begin{array}{l}\text { I thought it was important to notify him/her, because, if necessary, both } \\
\text { of us can be treated together and be healthy. Then, we'll be all right and } \\
\text { have a normal relationship again. }\end{array}$ \\
\hline & $\begin{array}{l}\text { Resentment in relation } \\
\text { to the partner }\end{array}$ & $\begin{array}{l}\text { I'm not sure whether to tell him/her or not. I guess I've been cheated on, } \\
\text { I don't want to have any contact with him/her anymore. }\end{array}$ \\
\hline \multirow{3}{*}{$\begin{array}{l}\text { How did you notify your } \\
\text { partner of the need to go to a } \\
\text { healthcare center? }\end{array}$} & $\begin{array}{l}\text { Verbal contact about } \\
\text { the notification }\end{array}$ & $\begin{array}{l}\text { I told him/her personally that the result of my test was positive and that } \\
\text { he/she should get tested and have a treatment if necessary. }\end{array}$ \\
\hline & $\begin{array}{l}\text { Telephone } \\
\text { communication }\end{array}$ & $\begin{array}{l}\text { I called him/her and told about the result of my test. I told him/her he/ } \\
\text { she should go to the healthcare center to get tested. }\end{array}$ \\
\hline & $\begin{array}{l}\text { Notification card } \\
\text { delivery }\end{array}$ & $\begin{array}{l}\text { I went to his/her house and gave him/her the notification card made by } \\
\text { the nurse. I didn't say anything else. }\end{array}$ \\
\hline
\end{tabular}


Regarding the perceptions of index patients, they mentioned they felt fear and insecurity when notifying their partners of the diagnosis, but they also mentioned mutual support and concern about the partner's health, and partner notification aiming to preserve the relationship. On the other hand, resentment in relation to the patient due to disease transmission was also mentioned. The notification methods mentioned were verbal contact, telephone communication and notification card delivery to sexual partners, which was freely selected by the patient after guidance provided in counseling. Only one healthcare center used notification cards.

Chart 2 shows the feelings reported by sexual partners at notification and the reasons for going to a healthcare center.

Chart 2 - Feelings reported by sexual partners at notification and reasons for going to a healthcare center - Fortaleza, Ceará, Brazil, March - July 2014.

\begin{tabular}{|c|c|c|}
\hline \multicolumn{3}{|c|}{ Sexual partner } \\
\hline Guiding question & Central idea & Collective Subject Discourse \\
\hline \multirow{5}{*}{$\begin{array}{l}\text { How did you feel when you } \\
\text { were notified/invited to go to a } \\
\text { healthcare center? }\end{array}$} & Tranquility & $\begin{array}{l}\text { When I was notified, I was calm, because I had already talked to people } \\
\text { who had sexually transmitted infections and I knew there was a treatment } \\
\text { for that. I was also glad because my partner was worried about my health. }\end{array}$ \\
\hline & Negative feelings & $\begin{array}{l}\text { I was worried, insecure, sad, a failure, and powerless because I could } \\
\text { have avoided this situation of risk. I even thought of killing myself. }\end{array}$ \\
\hline & $\begin{array}{l}\text { Consideration about the } \\
\text { possibility of death and } \\
\text { incurability }\end{array}$ & $\begin{array}{l}\text { I thought about death and the possibility of not living for a long time. I } \\
\text { was afraid because I thought I could have a serious untreatable disease. }\end{array}$ \\
\hline & $\begin{array}{l}\text { Fear of prejudice and } \\
\text { difficult support }\end{array}$ & $\begin{array}{l}\text { I thought of prejudice I would have to face in case of a positive result in the } \\
\text { test. I thought of how I'd tell my family and the acceptance of my family, } \\
\text { friends and colleagues. I also thought if I'd have support from a doctor and } \\
\text { other health professionals available in the public health system. }\end{array}$ \\
\hline & $\begin{array}{l}\text { Betrayal and changes in } \\
\text { the relationship }\end{array}$ & $\begin{array}{l}\text { Although my partner said he/she didn't have another relationship except } \\
\text { with me, I didn't believe him/her. He/she has been the only partner } \\
\text { I've had all my life. I felt betrayed and I thought of some changes in our } \\
\text { relationship, and that perhaps we wouldn't be the same anymore. }\end{array}$ \\
\hline \multirow{4}{*}{$\begin{array}{l}\text { What made you accept this } \\
\text { invitation? }\end{array}$} & Fear of being ill & I was afraid of being ill, of having a positive result in my test. \\
\hline & $\begin{array}{l}\text { Attenuation of guilt related } \\
\text { to infection transmission }\end{array}$ & $\begin{array}{l}\text { I wanted to know if I had transmitted the virus to him/her and if I'm } \\
\text { guilty, I'll support my partner. }\end{array}$ \\
\hline & $\begin{array}{l}\text { Need to confirm the } \\
\text { diagnosis }\end{array}$ & $\begin{array}{l}\text { As my partner had a positive result in the test, I wanted to know if my } \\
\text { result would be positive too. Then, I got tested immediately to have the } \\
\text { confirmation. }\end{array}$ \\
\hline & Early start of treatment & $\begin{array}{l}\text { At first, I thought I wouldn't go to the healthcare center. But then, I } \\
\text { thought I'd better go and get tested and, if necessary, start the treatment } \\
\text { as soon as possible. }\end{array}$ \\
\hline
\end{tabular}

Regarding the sexual partners' perception of infection notification, different feelings were reported at the moment of notification, such as tranquility, negative feelings (worry, insecurity, sadness, failure, lack of power), fear of death and incurability, betrayal and fear of prejudice and difficult support in case of having such a stigmatized disease like HIV/Aids. The reasons for going to a healthcare center include fear of being ill, attenuation of guilt related to infection transmission, need to confirm the diagnosis and early start of treatment.

\section{DISCUSSION}

The embarrassment of index patients at partner notification and fear of partner reaction to the possibility of having an STI are feelings associated with important obstacles to partner notification ${ }^{(12-13)}$. However, in this study, the concern about the partner's health and self-reflection contributed to the index patient's decision to notify his/her partners. Besides the psychological aspects, successful notification may also be influenced by local social values and beliefs related to the advantages and disadvantages of partner notification ${ }^{(13)}$.

The negative feelings expressed by index patients and sexual partners show how complex notifying an STI diagnosis can be to both groups. In this study, the initial idea of index patients of not going to a healthcare center was mentioned, in agreement with the results of other studies ${ }^{(12-14)}$.

In this study, the initial dilemma of whether to notify the infection to partners or not was similar to the result of another study conducted with patients with HIV infection, which indicated conflicts of interest in partner notification, related to the resulting negative impact and the moral responsibility of notification ${ }^{(7)}$. Thus, efforts should be focused on morally balancing the benefits and consequences of this action ${ }^{(7)}$.

Regarding the relationship between partner notification and gender, studies highlight other obstacles to HIV diagnosis notification to sexual partners, such as fear of violence or being accused of cheating by women with the virus, resulting from gender inequalities ${ }^{(13,15-16)}$.

In agreement with this study, the results of an investigation showed that the intention to notify partners is a challenge to be overcome, due to the stigma associated with STIs, whose failure or success may be influenced by factors such as extramarital sexual relationships, gender identity, structure of power and type of affectional-sexual bond ${ }^{(12)}$. 
It is important to consider that an STI diagnosis may cause resentment when it involves an extramarital relationship. Confirmation of betrayal causes heartbreak and discomfort, with an impact on the relationship. Therefore, a health professional should be prepared to refrain from judgments and discuss with the index patient the best way to notify the diagnosis, especially because the fear of being rejected by the partner is one of the main obstacles to partner notification ${ }^{(12)}$.

When notifying the diagnosis to an index patient, the health professional should offer emotional support and equal care without judgments, providing guidance about the importance of an early diagnosis and treatment of sexual partners, aiming to empower index patients to make safe decisions in terms of partner notification and ensure the diagnosis will be effectively notified ${ }^{(7)}$.

In addition, the attention to STI notification is directly associated with the health of people who have sexual relations with index patients, thus, it is important to warn them of their ethical responsibility to create opportunities for diagnosis and treatment to sexual partners ${ }^{(17)}$. After being notified, partners may benefit with the access to health service and health promotion practices, with the possibility of having specialized care and follow-up, favoring the interruption of the transmission cycle and longer survival of sexual partners ${ }^{(7)}$.

An important fact in this study was that all partner notifications were made by the index patients themselves, which may be associated with the type of relationship they have, as this is the most viable notification method for stable relationships (with affectional bond regardless of a marital relationship) when compared to casual sex (outside the context of a relationship $)^{(13,18)}$. On the other hand, it may be a concern if the sexual behavior with high potential for STI transmission, in particular HIV, is focused on casual $\operatorname{sex}^{(4)}$. However, the lack of studies addressing this theme in Brazil does not allow to have a better understanding of how partners are being notified by health services.

Delegating partner notification to index patients only, without considering their ambitions and desires, the healthcare infrastructure for partner notification and the instruments available for this action may lead to ineffective interruption of the STI transmission cycle. Thus, health administrators should consider an organizational structure of healthcare centers aiming to ensure human and material resources, coverage of an integrated service network, and opportunities for permanent education to allow successful partner notification ${ }^{(12)}$.

In this study, the participants did not mention any structural obstacle to notification. However, at international level, health services are challenged to prove proper conditions for partner notification. In different regions of the world, contact from sexual partners with healthcare centers is affected not only by sociocultural obstacles, but also by inadequate infrastructure offering a limited number of STI centers, short time dedicated to this health service, lack of trained staff and reliable diagnostic methods, and absence of partner notification guidelines ${ }^{(12)}$.

At national level, an important structural obstacle is the syndromic management of patients with STIs, an alternative to compensate the lack of laboratory diagnostic methods ${ }^{(3)}$, and which may be one important reason why partner notification is not integrated into the care of health profession$\mathrm{als}^{(12,19)}$. In this study, it may be associated with the predominance of reasons for partner notification having resulted from HIV and syphilis diagnosis, which may indicate failure in the control of other STIs in the country, due to the syndromic management of cases ${ }^{(19)}$.

On the other hand, HIV infection is still characterized by stigma and fear of transmission. Thus, people are concerned about the disease severity and incurability, a situation that contributes to more concrete actions from health services and the decision of index patients towards partner notification, once the notification may cause questioning, suspicion of cheating and guilt due to transmitted infection ${ }^{(16-17)}$.

Regarding syphilis, the increased number of notifications, besides reducing serious complications, particularly in pregnancy, is an important component in infection transmission interruption, especially due to the increasing number of cases in the country, mainly of congenital syphilis in which untreated partners are one of the reasons why it is uncontrolled in Brazil ${ }^{(6)}$.

Partner notification methods used by index patients varied in this study, as they used verbal contact, telephone communication or notification card delivery. However, the selection of the most convenient notification method may be related to the desire to make it a less traumatic experience due to any negative reaction the partner may have when being notified ${ }^{(20)}$.

When an index patient is responsible for partner notification, the Ministry of Health recommends the health professional hands the patient a notification card, which allows to identify the partner when he/she comes to the healthcare center. When an index patient refuses to hand the card or if the sexual partner does not go to the healthcare center within 15 days, health professionals may contact partners by letter or other methods, provided data confidentiality is ensured (telephone number and/or e-mail) ${ }^{(3)}$.

Regarding the notification card applicability, index patients indicated this method allowed partner notification without further questioning, which appears to be a convenient method to prevent embarrassing situations. However, further studies should be conducted to have a better understanding of the effectiveness of this type of notification in Brazil.

As a result of several developments in information and communication technology, for STI notification, the insertion of new methods has been recommended to expand the contact from sexual partners, such as internet, telephone, mobile devices and applications ${ }^{(21-22)}$. One example of an innovative action implemented in the United Kingdom was offering telephone consultation with a physician or pharmacist to sexual partners of people with bacterial STIs to expand partner access to the treatment ${ }^{(5)}$.

In this study, the perception of partner tranquility while being notified may be related to the fact that most of these infections are asymptomatic, a factor that does not attenuate STI complications in this stage. While bacterial infections are treatable and curable, viral infections, particularly HPV and HIV, may cause serious complications, especially in women. Syphilis, gonorrhea and chlamydia in women and 
hepatitis B, when undetected, lead to serious complications, such as congenital syphilis, pelvic inflammatory disease, infertility and cirrhosis ${ }^{(3)}$. Thus, counseling services should address the aspects related to consequences of the failure to include sexual partners in the treatment, gender issues and vulnerabilities to STI, especially due to non-habitual adoption of male and female condom.

Sexual partners' recognition of the importance of an early diagnosis and treatment leads to reduced risk behavior with an early diagnosis of HIV infection, and the treatment significantly reduces the plasma viral load, assuming an important role as a preventive intervention and in the attempt to reduce infection transmission ${ }^{(23)}$.

In terms of programmatic vulnerability, care to people with STI integrated with the primary care in Brazil presents fragilities, especially regarding partner access to diagnosis and treatment, which indicates the need to reorganize health services by integrating the service network and reinforcing the dialog among the involved bodies ${ }^{(24)}$.

In general, the challenges involved in STI notification are associated with esteem, fear of discrimination or impact on his/her image in relation to the partner ${ }^{(25)}$. Thus, these are important aspects to be addressed by health professionals during counseling, particularly nurses, for their presence in actions of education, counseling and identification of STI cases ${ }^{(26)}$ through rapid testing ${ }^{(9)}$. In addition, for comprehensive care to people with STI and their sexual partners in Brazil, health professionals are recommended to be prepared for the provision of individual and collective prevention, diagnosis of asymptomatic STI, management of symptomatic STI with flowcharts with/without a laboratory, partner notification and epidemiological notification of $\operatorname{cases}^{(3)}$.

\section{CONCLUSION}

Index patients, even when encouraged to notify their diagnosis to sexual partners, had negative feelings regarding partner notification, including resentment, insecurity, and above all fear of partner reaction and losing trust in the relationship, reflecting the complexity involved in the partner inclusion in the management of STI cases.

When receiving the diagnosis notification, partners had distinct perceptions of tranquility, betrayal, fear of death, incurability and diagnosis, particularly of HIV. In addition, fear of being ill, attenuation of guilt related to infection transmission, need to confirm the diagnosis and early start of treatment encouraged partners to go to a healthcare center.

Different methods of partner notification were mentioned by index patients: verbal contact, telephone communication and notification card delivery to sexual partners. Active search was not mentioned, a fact that may be associated with the lack of details in the national protocol of STI about how to conduct an active search based on a legal organizational structure.

Efforts to value partner notification in health services are required, once this action goes beyond individual interest. Thus, the development of guidelines with definition of responsibilities of everyone involved is essential, offering the necessary infrastructure, and guidance about how to address index patients and their partners, respecting data confidentiality and the singularity of each case. For this reason, it is important to recognize this action as one of the pillars of STI control, particularly of HIV, as it allows to reduce the probability of future infection acquisition or transmission.

This study suggests the addition of alternative methods of partner notification besides conventional options, such as internet, mobile applications, social media or a notification system integrated with health services, for easy contact from sexual partners. Considering the different options of partner notification, future studies are required to analyze their applicability or effectiveness in the perspective of all actors involved, which would help develop more adequate partner notification guidelines to health services in Brazil.

The limitation of this study referred to the fact that it did not investigate couples or pairs of index patients and their respective sexual partners.

\section{RESUMO}

Objetivo: Conhecer as percepções dos pacientes com infecções sexualmente transmissíveis e parceiros sexuais sobre a notificação da infecção. Método: Estudo descritivo e qualitativo, baseado na técnica do discurso do sujeito coletivo, realizado em quatro Unidades de Saúde de referência em Fortaleza/CE, de março a julho de 2014. Amostra composta por 21 sujeitos (11 pacientes-índice e 10 parceiros notificados). Resultados: Pacientes-índice relataram cumplicidade, preocupação com a saúde do parceiro e revelação do diagnóstico como forma de preservação do relacionamento. Para os parceiros, as percepções foram antagônicas: tranquilidade-traição, medo da morte, da incurabilidade e do diagnóstico, especialmente do HIV. Os motivos para o comparecimento foram: medo de estar doente, atenuação da culpa relativa à transmissão, necessidade do diagnóstico, início precoce do tratamento. Conclusão: Predominou o medo da quebra da confiança, inseguranças em lidar com uma infecção sexual e ser responsável ou corresponsável pela transmissão. As formas de comunicação às parcerias sexuais foram diversificadas (verbal, telefone, cartão de comunicação), atendendo a uma conveniência individual. Sugere-se a união de métodos alternativos de notificação e um sistema de notificação integrado.

\section{DESCRITORES}

Doenças Sexualmente Transmissíveis; Infecções por HIV; Parceiros Sexuais; Busca de Comunicante; Enfermagem em Saúde Pública.

\section{RESUMEN}

Objetivo: Conocer las percepciones de los pacientes con infecciones transmitidas sexualmente y parejas sexuales sobre la notificación de la infección. Método: Estudio descriptivo y cualitativo, basado en la técnica del discurso del sujeto colectivo, llevado a cabo en cuatro Unidades Sanitarias de referencia en Fortaleza/CE, de marzo a julio de 2014. Muestra compuesta de 21 sujetos (11 pacientes índice y 10 parejas notificadas). Resultados: Pacientes índice relataron complicidad, preocupación con la salud de la pareja y revelación del diagnóstico como forma de preservación de la relación. Para las parejas, las percepciones fueron antagónicas: tranquilidad-traición, 
miedo de la muerte, de la incurabilidad y el diagnóstico, especialmente del VIH. Los motivos para la comparecencia fueron: miedo de estar enfermo, atenuación de la culpa relativa a la transmisión, necesidad del diagnóstico, inicio precoz del tratamiento. Conclusión: Predominó el miedo de la ruptura de la confianza, inseguridades al manejar una infección sexual y ser responsable o corresponsable de la transmisión. Las formas de comunicación a las parejas sexuales fueron diversificadas: verbal (teléfono, tarjeta de comunicación), atendiendo a una conveniencia individual. Se sugiere la unión de métodos alternativos de notificación y un sistema de notificación integrado.

\section{DESCRIPTORES}

Enfermedades de Transmisión Sexual; Infecciones por VIH; Parejas Sexuales; Trazado de Contacto; Enfermería en Salud Pública.

\section{REFERENCES}

1. Ward H, Bell G. Partner notification. Medicine (Abington). 2014;42(6):314-7.

2. European Centre for Disease Prevention and Control. Public health benefits of partner notification for sexually transmitted infections and HIV. Stockholm: ECDC; 2013.

3. Brasil. Ministério da Saúde; Comissão Nacional de Incorporação de Tecnologias do SUS. Protocolo Clínico e Diretrizes Terapêuticas Infecções Sexualmente Transmissíveis [Internet]. Brasília: CONITEC; 2015 [citado 2015 jun. 22]. Disponível em: http://conitec.gov.br/ images/Consultas/Relatorios/2015/Relatorio_PCDT_IST_CP.pdf

4. Brown LB, Miller WC, Kamanga G, Nyirenda N, Mmodzi P, Pettifor A, et al. HIV Partner notification is effective and feasible in sub-Saharan Africa: opportunity for HIV treatment and prevention. J Acquir Immune Defic Syndr. 2011;;56(5):437-42 .

5. Althaus CL, Turner KME, Mercer CH, Auguste P, Roberts TE, Bell G, et al. Effectiveness and cost-effectiveness of traditional and new partner notification technologies for curable sexually transmitted infections: observational study, systematic reviews and mathematical modelling. Health Technol Assess. 2014;18(2):1-100.

6. Magalhães DMS, Kawaguchi IAL, Dias A, Calderon IMP. Sífilis materna e congênita: ainda um desafio. Cad Saúde Pública. 2013;29(6):110920.

7. Laar AK, DeBruin DA, Craddock S. Partner notification in the context of HIV: an interest-analysis. AIDS Res Ther. 2015;12:15.

8. Luz PM, Miranda KCL, Teixeira JMC. As condutas realizadas por profissionais de saúde em relação à busca de parceiros sexuais de pacientes soropositivos para o HIV/aids e seus diagnósticos sorológicos. Ciênc Saúde Coletiva. 2010;15 Supl. 1:1191-00.

9. Barbosa TLA, Gomes LMX, Holzmann APF, Paula AB, Haikal DSA. Aconselhamento em doenças sexualmente transmissíveis na atenção primária: percepção e prática profissional. Acta Paul Enferm. 2015;28(6):531-8.

10. Lefèvre F, Lefèvre AC. Discurso do sujeito coletivo: principais conceitos [Internet]. São Paulo: FSP/USP; 2005 [citado 2016 mar. 23 ]. Disponível em: http://hygeia.fsp.usp.br/quali-saude/Discurso_principais_conceitos.htm

11. Lefévre F, Lefévre AMC. Discurso do sujeito coletivo: um novo enfoque em pesquisa qualitativa (desdobramentos). Caxias do Sul: EDUCS; 2005.

12. Alam N, Chamot E, Vermund SH, Streatfield K, Kristensen S. Partner notification for sexually transmitted infections in developing countries: a systematic review. BMC Public Health. 2010;10:19.

13. Sabidó M, Gregg LP, Vallès X, Nikiforov M, Monzón JE, Pedroza MI, et al. Notification for sexually transmitted infections and HIV among sex workers in Guatemala: acceptability, barriers, and preferences. Sex Transm Dis. 2012;39(7):504-8.

14. Morris JL, Lippman SA, Philip S, Bernstein K, Neilands TB, Lightfoot M. Sexually transmitted infection related stigma and shame among African American male youth: implications for testing practices, partner notification, and treatment. AIDS Patient Care STDS. 2014;28(9):499-506.

15. Shamu S, Zarowsky C, Shefer T, Temmerman M, Abrahams N. Intimate partner violence after disclosure of HIV test results among pregnant women in Harare, Zimbabwe. Plos One. 2014;9(10):e109447.

16. Andrade RG, Iriart JAB. Estigma e discriminação: experiências de mulheres HIV positivo nos bairros populares de Maputo, Moçambique. Cad Saúde Pública. 2015;31(3):565-74.

17. Bell G, Potterat J. Partner notification for sexually transmitted infections in the modern world: a practitioner perspective on challenges and opportunities. Sex Transm Infect. 2011;87 Suppl 2:ii34-6.

18. Edelman EJ, Gordon KS, Hogben M, Crystal S, Bryant K, Justice AC. Sexual partner notification of HIV infection among a National United States-based sample of HIV-infected men. AIDS Behav. 2014;18(10):1898-903.

19. Cavalcante GFC, Araujo MAL, Galvão MTG, Moura HJ, Gondim APS, Silva RM. Sexually transmitted infections associated syndromes assisted in the primary health care in Northeast, Brazil. BMC Public Health. 2012;12:595.

20. Paiva V, Segurado AC, Filipe EMV. Self- disclosure of HIV diagnosis to sexual partners by heterosexual and bisexual men: a challenge for HIV/AIDS care and prevention. Cad Saúde Pública. 2011;27(9):1699-710.

21. Clark JL, Segura ER, Perez-Brumer AG, Reisner SL, Peinado J, Salvatierra HJ, et al. Potential impact and acceptability of internet partner notification for men who have sex with men and transgender women recently diagnosed with STD in Lima, Peru. Sex Transm Dis. 2014;41(1):43-5.

22. Hochberg $\mathrm{CH}$, Berringer K, Schneider JA. Next-generation methods for HIV partner services: a systematic review. Sex Transm Dis. 2015;42(9):533-9. 
23. National Aids Trust. HIV partner notification: a missed opportunity? [Internet]. London: NAT; 2012 [cited 2015 June 22]. Available from: http://www.nat.org.uk/media/Files/Publications/May-2012-HIV-Partner-Notification.pdf

24. Val LF, Nichiata LYI. Comprehensiveness and programmatic vulnerability to STDS/HIV/AIDS in primary care. Rev Esc Enferm USP [Internet]. 2014 [cited 2015 June 22];48(n.spe):145-51. Available from: http://www.scielo.br/pdf/reeusp/v48nspe/0080-6234-reeusp-48esp-149.pdf

25. Maksud I. Silêncios e segredos: aspectos (não falados) da conjugalidade face à sorodiscordância para o HIV/AIDS. Cad Saúde Pública. 2012;28(6):1196-204.

26. Mark H, Dhir A, Roth C. CE: sexually transmitted infections in the United States: overview and update. Am J Nurs. 2015;115(9):34-44. 